\title{
Pengaruh Ekstrak Daun Salam (Eugenia polyantha) terhadap Kadar Glukosa Darah pada Mencit (Mus
}

\section{Musculus)}

\section{Roza Linda Duarsa ${ }^{*}$, Indah Lestari $\mathrm{DK}^{2}$, Sri Wahyuni Gayatri ${ }^{3}$, Aryanti Bamahry ${ }^{4}$,} Rasfayanah $\mathbf{F M}^{3}$

${ }^{1}$ Mahasiswa Program Studi Pendidikan Dokter, Fakultas Kedokteran, Universitas Muslim Indonesia, Makassar, Indonesia

${ }^{2}$ Departemen Ilmu Penyakit Dalam, Fakultas Kedokteran, Universitas Muslim Indonesia, Makassar, Indonesia

${ }^{3}$ Departemen Biokimia, Fakultas Kedokteran, Universitas Muslim Indonesia, Makassar, Indonesia

${ }^{4}$ Departemen Fisiologi, Fakultas Kedokteran, Universitas Muslim Indonesia, Makassar, Indonesia

*Corresponding Author. E-mail: rozaduarsa@gmail.com, Mobile number: +62 813-4026-1237

\begin{abstract}
ABSTRAK
Latar belakang: Diabetes mellitus merupakan penyakit metabolik dengan karakteristik hiperglikemia yang terjadi karena kelainan sekresi insulin, kinerja insulin, atau kedua-duanya. Menurut Kementerian Kesehatan Republik Indonesia (Kemenkes RI) tahun 2010, diperkirakan terus meningkat sampai 21,3 juta orang pada tahun 2030. Penelitian ini bertujuan untuk membuktikan pengaruh ekstrak daun salam atau Eugenia polyantha terhadap kadar glukosa darah pada mencit atau Mus musculus.

Metode: Penelitian ini merupakan penelitian true experiment dengan rancangan pre-test and post-test control group design, dimana pengukuran kadar glukosa darah pada mencit dilakukan sebelum dan sesudah perlakuan. Percobaan ini menggunakan mencit sebanyak 25 ekor, dibagi dalam 5 kelompok, masing-masing terdiri dari 5 ekor mencit. Kelompok 1 (kontrol negatif) diberi diet standar, kelompok 2 (kontrol positif) diinduksi aloksan monohidrat dosis $70 \mathrm{mg} / \mathrm{kgBB}$, kelompok 3 diberi ekstrak daun salam dosis $250 \mathrm{mg} / \mathrm{kgBB}$, kelompok 4 diberi ekstrak daun salam dosis $500 \mathrm{mg} / \mathrm{kgBB}$, dan kelompok 5 diberi ekstrak daun salam dosis $1000 \mathrm{mg} / \mathrm{kgBB}$.

Hasil: Ekstrak daun salam secara signifikan $(\mathrm{p}<0.05)$ dapat menurunkan kadar glukosa darah pada mencit. Dosis $250 \mathrm{mg} / \mathrm{kgBB}$ dapat menurunkan glukosa darah sampai kadar rata-rata $115,40 \mathrm{mg} / \mathrm{dL}$, dosis $500 \mathrm{mg} / \mathrm{kgBB}$ yaitu $115,00 \mathrm{mg} / \mathrm{dL}$, dan dosis $1000 \mathrm{mg} / \mathrm{kgBB}$ yaitu $91,40 \mathrm{mg} / \mathrm{dL}$.

Kesimpulan: bahwa ekstrak daun salam dapat menurunkan kadar glukosa darah pada mencit dan efektivitas ekstrak daun salam lebih baik pada dosis $1000 \mathrm{mg} / \mathrm{kgBB}$ dibandingkan dosis $250 \mathrm{mg} / \mathrm{kgBB}$ dan dosis 500 $\mathrm{mg} / \mathrm{kgBB}$.
\end{abstract}

Kata kunci: Eugenia polyantha; glukosa darah; Mus musculus; aloksan

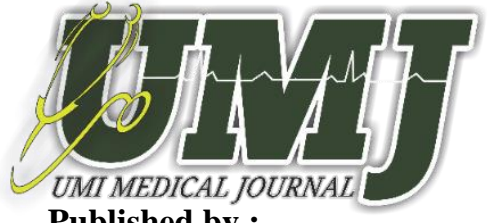

Published by :

Fakultas Kedokteran

Universitas Muslim Indonesia

Phone:

+6282293330002
Article history:

Received: 01 Mei 2020

Accepted: 23 Juni 2020

Published: 28 Desember2020
Address:

Jl. Urip Sumoharjo Km. 5 (Kampus II UMI)

Makassar, Sulawesi Selatan.

Email:

medicaljournal@umi.ac.id 


\section{ABTRACT}

Background: Diabetes mellitus is a metabolic disease with hyperglycemia criteria that occurs due to abnormalities in insulin secretion, insulin performance, or both. According to the Ministry of Health of the Republic of Indonesia (Kemenkes RI) in 2010, it is estimated that it will continue to increase to 21.3 million people in 2030. This study aims to prove the effect of bay leaf extract or Eugenia polyantha on blood glucose levels in mice or Mus musculus.

Methods: This study is a true study with a pre-test design and a post-test control group design, in which the measurement of blood glucose levels was carried out before and after treatment. The experiment used 25 mice, divided into 5 groups, each consisting of 5 mice. Group 1 (negative control) was given a standard diet, group 2 (positive control) was induced by $70 \mathrm{mg} / \mathrm{kg}$ of alloxan monohydrate, group 3 was given bay leaf extract at a dose of $250 \mathrm{mg} / \mathrm{kg}$, group 4 was given bay leaf extract at a dose of $500 \mathrm{mg} / \mathrm{kg}$, and group 5 were given bay leaf extract at a dose of $1000 \mathrm{mg} / \mathrm{kgBW}$.

Results: The bay leaf extract significantly $(\mathrm{p}<0.05)$ reduced blood glucose levels in mice. Doses of $250 \mathrm{mg} / \mathrm{kgBW}$ can reduce glucose to an average level of $115.40 \mathrm{mg} / \mathrm{dL}$, a dose of $500 \mathrm{mg} / \mathrm{kgBB}$ is $115.00 \mathrm{mg} / \mathrm{dL}$, and a dose of $1000 \mathrm{mg} / \mathrm{kgBW}$ is $91.40 \mathrm{mg} / \mathrm{dL}$.

Conclusion: bay leaf extract can reduce blood glucose levels in mice and bay leaf extract is better at a dose of $1000 \mathrm{mg} / \mathrm{kgBW}$ compared to a dose of $250 \mathrm{mg} / \mathrm{kgBW}$ and a dose of $500 \mathrm{mg} / \mathrm{kgBW}$.

Keywords: Eugenia polyantha; blood sugar; Mus musculus; aloksan

\section{PENDAHULUAN}

Hiperglikemia merupakan suatu kondisi medik berupa peningkatan kadar glukosa dalam darah yang melebihi batas normal serta salah satu tanda khas dari penyakit diabetes mellitus (DM). ${ }^{1}$ Menurut American Diabetes Association (ADA), diabetes mellitus adalah suatu kelompok penyakit metabolik dengan karakteristik hiperglikemia yang terjadi karena kelainan sekresi insulin, kinerja insulin atau kedua-duanya. ${ }^{1,2}$ Menurut World Health Organization (WHO), diabetes mellitus (DM) didefinisikan sebagai suatu penyakit atau gangguan metabolisme kronis dengan multi etiologi yang ditandai dengan tingginya kadar gula darah disertai dengan gangguan metabolisme karbohidrat, lipid, dan protein sebagai akibat dari insufisiensi fungsi insulin. Insufisiensi insulin dapat disebabkan oleh gangguan produksi insulin oleh sel-sel beta Langerhans kelenjar pankreas atau disebabkan oleh kurangnya respon sel-sel tubuh terhadap insulin..$^{1,2,3}$

Penyakit ini merupakan salah satu penyebab kematian terbanyak ke-3 di dunia setelah penyakit kanker dan kardiovaskuler pada penduduk dengan rentang usia 30-70 tahun. Negara Indonesia menduduki peringkat ke- 4 tertinggi di dunia setelah Amerika Serikat, China, dan India. ${ }^{4}$ Berdasarkan data yang diperoleh dari International Diabetes Federation (IDF), bahwa setiap 7 detik 1 orang di dunia meninggal karena menderita diabetes mellitus. Selain itu, 1 dari 12 orang menderita diabetes mellitus dan 1 dari 2 orang penderita itu tidak mengetahui bahwa ia menderita diabetes mellitus. WHO membuat perkiraan bahwa pada tahun 2000, jumlah pengidap diabetes melitus di atas umur 20 tahun berjumlah 150 juta orang. Dalam kurun waktu 25 tahun kemudian, jumlah tersebut akan meningkat menjadi 300 juta orang. ${ }^{4}$

Data terakhir WHO (2005), menunjukkan bahwa peningkatan tertinggi jumlah penderita diabetes mellitus terjadi di Asia Tenggara. Indonesia akan mendapatkan jumlah pasien sebanyak 12,4 juta orang pada tahun 2025. Menurut Kementerian Kesehatan Republik Indonesia (Kemenkes RI) tahun 2010, diperkirakan akan terus meningkat sampai 21,3 juta orang pada tahun 2030. Berdasarkan data dari Dinas Kesehatan Kota Makassar (2015), angka 
kejadian penyakit diabetes mellitus pada tahun 2011 sebanyak 5.700 kasus. Pada tahun 2012 meningkat menjadi 14.067 kasus, tahun 2013 menjadi 14.604 dan semakin meningkat di tahun 2014 menjadi 21.452 kasus. $^{5}$

Prevalensi diabetes mellitus yang cenderung meningkat membuat banyak peneliti tertarik untuk mengembangkan obat anti diabetes mellitus. Obat Hipoglikemik Oral $(\mathrm{OHO})$ efektif menurunkan kadar gula darah yang tinggi, namun komplikasi yang ditimbulkan oleh diabetes mellitus masih belum bisa dicegah dengan baik sehingga masih diperlukan upaya untuk mencari obat baru dengan kemampuan anti diabetes fisiologis yang tepat sasaran, aman, dan mudah terjangkau (ekonomis). ${ }^{6}$

Salah satu obat non farmakologi yang dapat digunakan untuk penyakit diabetes mellitus adalah daun salam. Daun salam (Eugenia polyantha) tersebar di berbagai daerah, baik di pegunungan maupun di dataran rendah. Menurut David dan Branen et al. (1993), kandungan kimia daun salam (Eugenia polyantha) adalah minyak atsiri yang mengandung sitral, eugenol, triterpenoid, tannin, saponin, dan flavonoid yang berpotensi untuk menurunkan kadar glukosa darah. Menurut Nublah et al. (2011), flavonoid memiliki kandungan antioksidan yang bersifat antidiabetik dan dapat menghambat reabsorbsi glukosa dari ginjal dan dapat meningkatkan kelarutan glukosa darah sehingga mudah diekskresikan melalui urin. ${ }^{6}$

Oleh karena itu, peneliti ingin melakukan penelitian secara ilmiah yang berjudul "Pengaruh Ekstrak Daun Salam (Eugenia polyantha) terhadap Kadar Glukosa Darah pada Mencit (Mus musculus)”.

\section{METODE}

Penelitian ini merupakan penelitian true experiment dengan rancangan penelitian pre-test and post-test control group design, dimana pengukuran kadar glukosa darah pada mencit dilakukan sebelum dan sesudah diberikan perlakuan. Penelitian dilakukan di Laboratorium Penelitian Fakultas Kedokteran Universitas Muslim Indonesia Makassar pada bulan Oktober-Desember 2019. Populasi pada penelitian ini adalah mencit jenis jantan berusia 2-3 bulan dengan berat badan 20-30 gram. Sampel sebanyak 25 ekor mencit dibagi ke dalam 5 kelompok dengan masingmasing kelompok berjumlah 5 ekor mencit. Alat yang digunakan pada penelitian ini, antara lain: Kandang mencit beserta tempat makan dan minum, timbangan elektrik, glukometer dan strip glukosa, blood lancet dan pen lancet, oral sonde lambung, spoit injeksi, handscoen dan masker, kertas saring, stoples, blender, dan hairdryer. Bahan yang digunakan antara lain: Daun salam yang telah dikeringkan, etanol $96 \%$, Na-CMC $1 \%$, aquabidestilasi steril for injection (aquadest), alcohol swab 70\%, dan aloksan monohidrat $70 \mathrm{mg} / \mathrm{kgBB}$.

Data yang diperoleh dianalisis secara statistik menggunakan SPSS. Pertama dilakukan uji Shapiro-Wilk untuk melihat normalitas distribusi data. Jika didapatkan nilai $\mathrm{p}>0.05$ maka data terdistribusi normal. Selanjutnya, dilakukan uji One Way Anova untuk melihat perbedaan kadar glukosa darah pada kelompok perlakuan. Jika didapatkan nilai $\mathrm{p}<0.05$ berarti terdapat perbedaan yang bermakna. Jika uji Shapiro-Wilk signifikan, maka dilanjutkan dengan uji $\mathrm{T}$ berpasangan untuk membandingkan rerata kadar glukosa darah sebelum dan sesudah perlakuan. Jika didapatkan nilai $\mathrm{p}<0,05$ berarti terdapat perubahan yang bermakna. Jika uji One Way Anova signifikan, maka dilanjutkan dengan uji Post Hoc LSD (Least Significant Difference) untuk mengetahui perbedaan antar kelompok. Jika didapatkan nilai $\mathrm{p}<0.05$ berarti terdapat perbedaan yang bermakna. 


\section{HASIL PENELITIAN}

Daun salam yang telah dimaserasi dengan pelarut etanol 96\% selama 5 × 24 jam dan setelah itu dipanaskan hingga menjadi ekstrak kental dan ditimbang maka didapatkan dengan berat 7,9 gram. Pengukuran kadar glukosa darah dilakukan pada hari ke-1 sebelum diinduksi aloksan, hari ke-6 setelah diinduksi aloksan, hari ke-13 dan hari ke-20 setelah pemberian ekstrak daun salam. Pengukuran kadar glukosa darah dilakukan pada tiap kelompok perlakuan yang sebelumnya telah dipuasakan selama 16 jam. Hasil pengukuran kadar glukosa darah disajikan pada tabel berikut.

Tabel 1. Kadar glukosa darah puasa pada tiap kelompok perlakuan

\begin{tabular}{|c|c|c|c|c|}
\hline \multirow[b]{2}{*}{ Kelompok Perlakuan } & \multicolumn{4}{|c|}{ Kadar Glukosa Darah (mg/dL) } \\
\hline & $\begin{array}{c}\text { H1 } \\
\mathrm{n}=5\end{array}$ & $\begin{array}{c}\mathrm{H6} \\
\mathrm{n}=5\end{array}$ & $\begin{array}{l}\mathrm{H13} \\
\mathrm{n}=5\end{array}$ & $\begin{array}{c}\mathbf{H} 20 \\
\mathrm{n}=5\end{array}$ \\
\hline \multirow{6}{*}{$\begin{array}{l}\text { Kelompok } 1 \\
\text { (Kontrol negatif) }\end{array}$} & 112 & 227 & 166 & 106 \\
\hline & 129 & 183 & 107 & 101 \\
\hline & 124 & 211 & 129 & 115 \\
\hline & 101 & 216 & 148 & 123 \\
\hline & 129 & 196 & 154 & 79 \\
\hline & $119,00 \pm$ & $206,60 \pm$ & $140,80 \pm$ & $104,80 \pm$ \\
\hline$(\mathrm{Mean} \pm \mathrm{SD})$ & 12,23 & 17,27 & 23,15 & 16,71 \\
\hline \multirow{6}{*}{$\begin{array}{l}\text { Kelompok } 2 \\
\text { (Kontrol positif) }\end{array}$} & 148 & 211 & 138 & 138 \\
\hline & 139 & 534 & 153 & 96 \\
\hline & 107 & 196 & 121 & 118 \\
\hline & 154 & 192 & 78 & 123 \\
\hline & 116 & 184 & 150 & 107 \\
\hline & $132,80 \pm$ & $263,40 \pm$ & $128,00 \pm$ & $116,40 \pm$ \\
\hline$(\mathrm{Mean} \pm \mathrm{SD})$ & 20,41 & 151,59 & 30,65 & 15,95 \\
\hline \multirow{6}{*}{$\begin{array}{l}\text { Kelompok } 3 \\
\text { (Ekstrak daun salam dosis } 250 \\
\mathrm{mg} / \mathrm{kgBB} \text { ) }\end{array}$} & 168 & 211 & 147 & 124 \\
\hline & 167 & 192 & 78 & 107 \\
\hline & 127 & 183 & 123 & 134 \\
\hline & 176 & 202 & 112 & 99 \\
\hline & 174 & 211 & 119 & 113 \\
\hline & $162,40 \pm$ & $199,80 \pm$ & $115,80 \pm$ & $115,40 \pm$ \\
\hline$(\mathrm{Mean} \pm \mathrm{SD})$ & 20,16 & 12,24 & 24,89 & 13,83 \\
\hline
\end{tabular}




\begin{tabular}{|c|c|c|c|c|}
\hline Kelompok 4 & 139 & 179 & 147 & 113 \\
\hline (Ekstrak daun salam dosis 500 & 173 & 217 & 172 & 113 \\
\hline \multirow[t]{5}{*}{$\mathrm{mg} / \mathrm{kgBB})$} & 118 & 227 & 173 & 127 \\
\hline & 148 & 195 & 144 & 84 \\
\hline & 138 & 183 & 134 & 138 \\
\hline & $143,20 \pm$ & $200,20 \pm$ & $154,00 \pm$ & $115,00 \pm$ \\
\hline & 19,94 & 21,05 & 17,56 & 20,26 \\
\hline \multirow{6}{*}{$\begin{array}{l}\text { Kelompok } 5 \\
\text { (Ekstrak daun salam dosis } 1000 \\
\mathrm{mg} / \mathrm{kgBB} \text { ) }\end{array}$} & 162 & 180 & 98 & 91 \\
\hline & 171 & 211 & 101 & 118 \\
\hline & 158 & 291 & 152 & 75 \\
\hline & 162 & 211 & 126 & 69 \\
\hline & 138 & 247 & 142 & 104 \\
\hline & $158,20 \pm$ & $228,00 \pm$ & $123,80 \pm$ & $91,40 \pm$ \\
\hline$(\mathrm{Mean} \pm \mathrm{SD})$ & 12,26 & 42,46 & 24,07 & 20,23 \\
\hline
\end{tabular}

H1: Kadar GDP awal sebelum pemberian uji (hari ke-1); H6: Kadar GDP setelah diinduksi aloksan monohidrat dosis 70 mg/kgBB (hari ke-6); H13: Kadar GDP setelah diberi ekstrak daun salam pada minggu pertama (hari ke-13); H20: Kadar GDP setelah diberi ekstrak daun salam pada minggu kedua (hari ke-20); SD: Standar Deviasi

Pada tabel 1 di atas, semua kelompok perlakuan memiliki kadar glukosa darah yang normal pada hari ke-1. Hal ini dapat dilihat dari nilai rerata pada kelompok 1: 119,00 mg/dL, kelompok 2: 132,80 mg/dL, kelompok 3 : 162,40 mg/dL, kelompok 4: 143,20 mg/dL, dan kelompok 5: 158,20 mg/dL. Hal ini menunjukkan bahwa seluruh hewan coba memiliki kadar glukosa darah yang normal $(62,8-176 \mathrm{mg} / \mathrm{dL})$.

Pada hari ke-6 setelah diinduksi aloksan, semua kelompok perlakuan mengalami peningkatan kadar glukosa darah, kecuali pada kelompok 1 tidak diinduksi aloksan meskipun kadar glukosa darahnya juga meningkat. Perbedaan respon tubuh pada masing-masing mencit yang mengalami kerusakan sel $\beta$ pankreas sebagai efek dari induksi aloksan meskipun dosis yang diberikan sama. Hal ini dapat dilihat dari nilai rerata pada kelompok 1:206,60 mg/dL, kelompok 2: 263,40 mg/dL, kelompok 3: 199,80 mg/dL, kelompok 4: 200,20 mg/dL, dan kelompok 5: 228,00 mg/dL. Hal ini menunjukkan bahwa seluruh hewan coba mengalami hiperglikemia (> $176 \mathrm{mg} / \mathrm{dL})$.

Pada hari ke-13, semua kelompok perlakuan mengalami penurunan kadar glukosa darah. Pemberian ekstrak daun salam yang diujikan pada kelompok 3, kelompok 4, dan kelompok 5 dengan dosis yang bervariasi mengalami penurunan kadar glukosa darah. Pada kelompok 1 dan kelompok 2 tidak diberikan ekstrak daun salam meskipun kadar glukosa darahnya juga menurun. Hal ini dapat dilihat dari nilai rerata pada kelompok 1: 140,80 mg/dL, kelompok 2: 128,00 mg/dL, kelompok 3: 115,80 mg/dL, kelompok 4: 154,00 mg/dL, dan kelompok 5: 123,80 mg/dL. Hal ini menunjukkan bahwa kadar glukosa darah pada seluruh hewan coba kembali normal (62,8-176 mg/dL).

Pada hari ke-20, semua kelompok perlakuan juga mengalami penurunan kadar glukosa darah. Sama halnya pada hari ke-13, pada kelompok 3, kelompok 4, dan kelompok 5 diberikan ekstrak daun salam, sedangkan pada 
kelompok 1 dan kelompok 2 tidak diberikan ekstrak daun salam meskipun kadar glukosa darahnya juga menurun. Hal ini dapat dilihat dari nilai rerata pada kelompok 1: 104,80 mg/dL, kelompok 2: 116,40 mg/dL, kelompok 3 : 115,40 mg/dL, kelompok 4: 115,00 mg/dL, dan kelompok 5: 91,40 mg/dL. Hal ini menunjukkan bahwa kadar glukosa darah pada seluruh hewan coba juga kembali normal $(62,8-176 \mathrm{mg} / \mathrm{dL})$.

Untuk memudahkan melihat perubahan kadar glukosa darah pada tiap kelompok perlakuan, maka hasil penginputan data dari Microsoft Excel disajikan dalam bentuk grafik berikut.

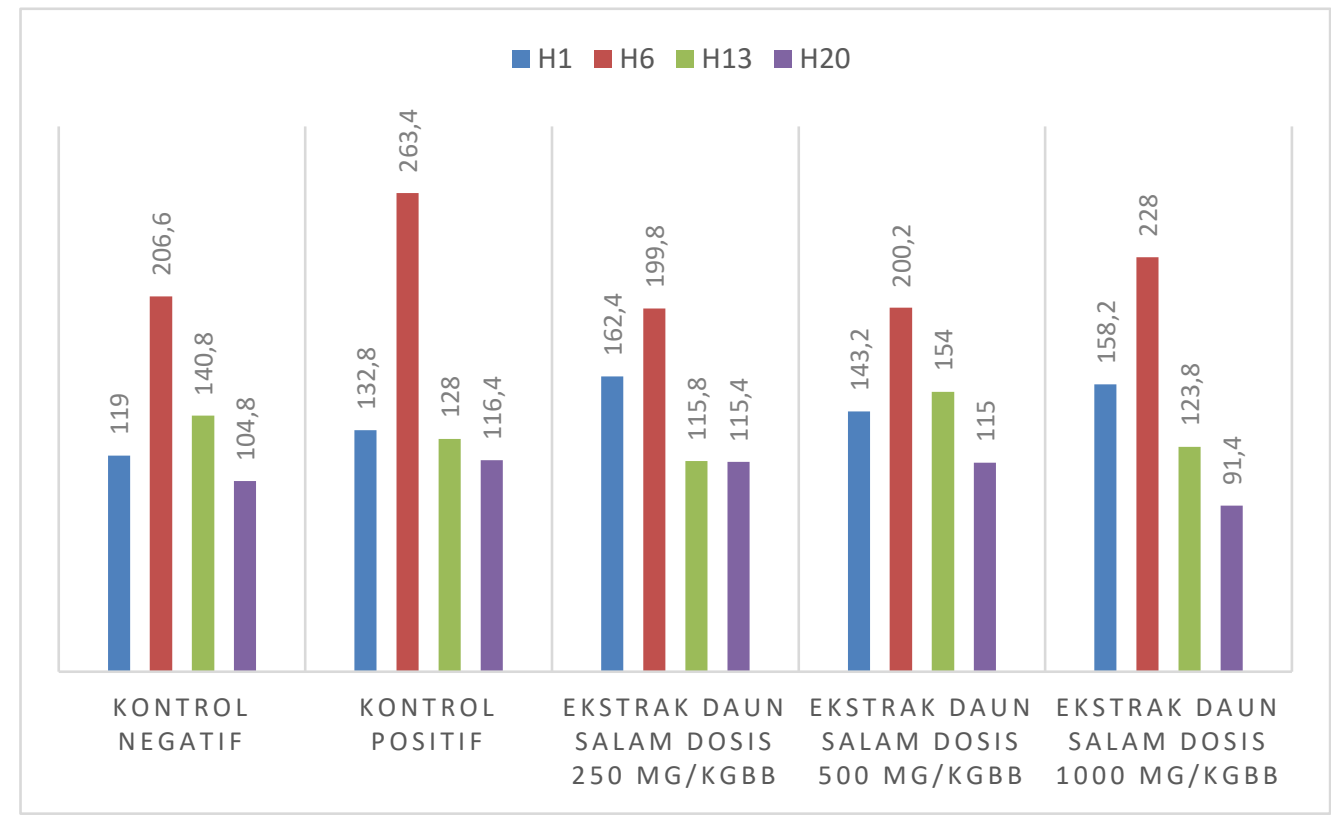

Gambar 1. Grafik rerata kadar GDP pada seluruh kelompok

Pada gambar 1 di atas, dapat dilihat bahwa kadar glukosa darah mencit sebelum diinduksi aloksan pada H1 relatif berbeda namun masih dalam batas normal (62,8-176 mg/dL). Setelah diinduksi aloksan pada H6, seluruh kelompok mengalami peningkatan kadar glukosa darah yang bervariasi (>176 mg/dL). Kenaikan yang paling besar terjadi pada kelompok 2 (kontrol positif) dengan nilai rerata 263,40 mg/dL. Pada H13, terlihat penurunan kadar glukosa darah pada seluruh kelompok. Penurunan yang paling besar terjadi pada kelompok 3 (ekstrak daun salam dosis $250 \mathrm{mg} / \mathrm{kgBB}$ ) dengan nilai rerata 115,80 mg/dL dibandingkan dengan kelompok 4 (ekstrak daun salam dosis $500 \mathrm{mg} / \mathrm{kgBB}$ ) dengan nilai rerata 154,00 mg/dL dan kelompok 5 (ekstrak daun salam dosis $1000 \mathrm{mg} / \mathrm{kgBB}$ ) dengan nilai rerata 123,80 mg/dL. Pada H20 juga terlihat penurunan kadar glukosa darah pada seluruh kelompok. Penurunan yang paling besar terjadi pada kelompok 5 (ekstrak daun salam dosis $1000 \mathrm{mg} / \mathrm{kgBB}$ ) dengan nilai rerata 91,40 mg/dL dibandingkan dengan kelompok 3 (ekstrak daun salam dosis $250 \mathrm{mg} / \mathrm{kgBB}$ ) dengan nilai rerata 115,40 mg/dL dan kelompok 4 (ekstrak daun salam dosis $500 \mathrm{mg} / \mathrm{kgBB}$ ) dengan nilai rerata 115,00 mg/dL.

Data hasil pengukuran kadar glukosa darah dianalisa menggunakan uji statistik. Langkah pertama analisis data pada penelitian ini yaitu dengan mengetahui distribusi data. Distribusi data bisa diketahui setelah dilakukan uji normalitas data menggunakan uji Shapiro-Wilk. Uji ini digunakan untuk kelompok dengan populasi yang kecil, yaitu 
$<50$ sampel. Jika nilai p>0,05 maka dinyatakan data terdistribusi normal. Hasil uji normalitas data dengan uji Shapiro-Wilk disajikan pada tabel berikut.

Tabel 2. Uji normalitas data kadar glukosa darah pada seluruh kelompok perlakuan

\begin{tabular}{cccc}
\hline Waktu & Statistik & df & Sig. \\
\hline H1 & 0.949 & 25 & 0.235 \\
H6 & 0.484 & 25 & 0.000 \\
H13 & 0.954 & 25 & 0.306 \\
H20 & 0.966 & 25 & 0.535 \\
*Uji Shapiro-Wilk & \multicolumn{2}{c}{ Sumber: Data Primer 2019 }
\end{tabular}

Pada tabel 2 di atas, dapat dilihat bahwa pada H1, H13, dan H20 memiliki nilai p > 0,05 sehingga data tersebut terdistribusi normal, sedangkan pada H6 $(\mathrm{p}=0.000)$ memiliki nilai $\mathrm{p}<0,05$ sehingga data tersebut tidak terdistribusi normal. Data yang terdistribusi normal akan dianalisa menggunakan uji One Way Anova, sedangkan data yang tidak terdistribusi normal akan dianalisa menggunakan uji Kruskal-Wallis. Uji ini dilakukan untuk mengetahui ada atau tidaknya perbedaan pada kelompok perlakuan. Jika nilai $\mathrm{p}<0,05$ berarti terdapat perbedaan yang bermakna. Hasil analisis dapat dilihat pada tabel berikut.

Tabel 3. Hasil uji One Way Anova

\begin{tabular}{|c|c|c|c|c|c|c|}
\hline \multicolumn{7}{|c|}{ ANOVA } \\
\hline Waktu & $\begin{array}{c}\text { Hasil } \\
\text { Pengukuran }\end{array}$ & $\begin{array}{l}\text { Sum of } \\
\text { Squares }\end{array}$ & df & $\begin{array}{c}\text { Mean } \\
\text { Square }\end{array}$ & $\mathbf{F}$ & Sig. \\
\hline \multirow[t]{6}{*}{ H1 } & Between Groups & 6437.040 & 4 & 1609.260 & 5.29 & 0.00 \\
\hline & & & & & 2 & 4 \\
\hline & Within Groups & 6081.600 & 2 & 304.080 & & \\
\hline & & & 0 & & & \\
\hline & Total & 12518.64 & 2 & & & \\
\hline & & 0 & 4 & & & \\
\hline \multirow[t]{6}{*}{$\mathrm{H} 13$} & Between Groups & 4529.840 & 4 & 1132.460 & 1.89 & 0.15 \\
\hline & & & & & 8 & 0 \\
\hline & Within Groups & 11930.40 & 2 & 596.520 & & \\
\hline & & 0 & 0 & & & \\
\hline & Total & 16460.24 & 2 & & & \\
\hline & & 0 & 4 & & & \\
\hline \multirow[t]{6}{*}{$\mathrm{H} 20$} & Between Groups & 2291.600 & 4 & 572.900 & 1.85 & 0.15 \\
\hline & & & & & 5 & 8 \\
\hline & Within Groups & 6178.400 & 2 & 308.920 & & \\
\hline & & & 0 & & & \\
\hline & Total & 8470.000 & 2 & & & \\
\hline & & & 4 & & & \\
\hline
\end{tabular}

*Uji One Way Anova

Sumber: Data Primer 2019

Pada tabel 3 di atas, dapat dilihat bahwa pada H1 $(\mathrm{p}=0.004)$ memiliki nilai $\mathrm{p}<0,05$ yang berarti terdapat perbedaan kadar glukosa darah yang bermakna pada seluruh kelompok perlakuan, sedangkan pada H13 ( $\mathrm{p}=0.150$ ) 
dan H20 ( $\mathrm{p}=0.158)$ memiliki nilai $\mathrm{p}>0,05$ yang berarti tidak terdapat perbedaan kadar glukosa darah yang bermakna pada seluruh kelompok perlakuan.

Begitu pula pada uji Kruskal-Wallis dimana pada H6 $(\mathrm{p}=0.789)$ memiliki nilai p>0,05 yang berarti tidak terdapat perbedaan kadar glukosa darah yang bermakna pada seluruh kelompok perlakuan.

Setelah dilakukan uji Shapiro-Wilk, maka dilanjutkan menggunakan uji $\mathrm{T}$ berpasangan (untuk data yang terdistribusi normal) dan uji Wilcoxon (untuk data yang tidak terdistribusi normal). Uji ini dilakukan untuk mengetahui ada atau tidaknya perubahan yang terjadi antara sebelum dan sesudah pada kelompok perlakuan. Jika nilai $p<0,05$ berarti terdapat perubahan yang bermakna. Hasil analisis dapat dilihat pada tabel berikut.

Tabel 4. Perubahan kadar glukosa darah pada H1 dan H6

\begin{tabular}{|c|c|c|c|c|}
\hline \multirow{2}{*}{$\begin{array}{l}\text { Kelompok } \\
\text { Perlakuan }\end{array}$} & \multicolumn{2}{|c|}{ Kadar Glukosa Darah (mg/dL) } & \multirow{2}{*}{$\begin{array}{l}\text { Selisih } \\
\text { Rerata } \\
\text { (mg/dL) }\end{array}$} & \multirow[b]{2}{*}{ Sig. } \\
\hline & $\begin{array}{c}\text { H1 } \\
\text { Mean } \pm \text { SD }\end{array}$ & $\begin{array}{c}\text { H6 } \\
\text { Mean } \pm \text { SD }\end{array}$ & & \\
\hline 1 & $119,00 \pm 12,23$ & $206,60 \pm 17,27$ & 87,60 & $0.002 *$ \\
\hline 2 & $132,80 \pm 20,41$ & $263,40 \pm 151,59$ & 130,60 & $0.043^{* *}$ \\
\hline 3 & $162,40 \pm 20,16$ & $199,80 \pm 12,24$ & 37,40 & $0.043 * *$ \\
\hline 4 & $143,20 \pm 19,94$ & $200,20 \pm 21,05$ & 57,00 & $0.012^{*}$ \\
\hline 5 & $158,20 \pm 12,26$ & $228,00 \pm 42,46$ & 69,80 & $0.033^{*}$ \\
\hline
\end{tabular}

Pada tabel 4 di atas, pada kelompok 2-kelompok 5 memiliki nilai $\mathrm{p}<0,05$ yang berarti terdapat perubahan kadar glukosa darah antara sebelum dan sesudah diinduksi aloksan pada seluruh kelompok, kecuali pada kelompok 1 hanya diberi diet standar namun juga terdapat perubahan yang bermakna. Perubahan yang paling besar terjadi pada kelompok $2(\mathrm{p}=0.043)$ dengan selisih rerata 130,60 mg/dL.

Tabel 5. Perubahan kadar glukosa darah pada H6 dan H13

\begin{tabular}{|c|c|c|c|c|}
\hline \multirow[b]{2}{*}{$\begin{array}{l}\text { Kelompok } \\
\text { Perlakuan }\end{array}$} & \multicolumn{2}{|c|}{ Kadar Glukosa Darah (mg/dL) } & \multirow{2}{*}{$\begin{array}{l}\text { Selisih } \\
\text { Rerata } \\
\text { (mg/dL) }\end{array}$} & \multirow[b]{2}{*}{ Sig. } \\
\hline & $\begin{array}{c}\text { H6 } \\
\text { Mean } \pm \text { SD }\end{array}$ & $\begin{array}{c}\text { H13 } \\
\text { Mean } \pm \text { SD }\end{array}$ & & \\
\hline 1 & $206,60 \pm 17,27$ & $140,80 \pm 23,15$ & 57,80 & $0.001^{*}$ \\
\hline 2 & $263,40 \pm 151,59$ & $128,00 \pm 30,65$ & 135,40 & $0.043 * *$ \\
\hline 3 & $199,80 \pm 12,24$ & $115,80 \pm 24,89$ & 84,00 & $0.043 * *$ \\
\hline 4 & $200,20 \pm 21,05$ & $154,00 \pm 17,56$ & 46,20 & $0.000^{*}$ \\
\hline 5 & $228,00 \pm 42,46$ & $123,80 \pm 24,07$ & 104,20 & $0.001 *$ \\
\hline
\end{tabular}

*Uji T berpasangan, **Uji Wilcoxon Sumber: Data Primer 2020

Pada tabel 5 di atas, dapat dilihat bahwa pada kelompok 3-kelompok 5 memiliki nilai $\mathrm{p}<0,05$ yang berarti terdapat perubahan kadar glukosa darah antara sebelum dan sesudah pemberian ekstrak daun salam pada kelompok tersebut, kecuali pada kelompok 1 dan kelompok 2 tidak diberi ekstrak daun salam namun juga terdapat perubahan yang bermakna. Perubahan yang paling besar terjadi pada kelompok 5 ( $\mathrm{p}=0.001)$ dengan selisih rerata $104,20 \mathrm{mg} / \mathrm{dL}$. 
Tabel 6. Perubahan kadar glukosa darah pada H6 dan H20

\begin{tabular}{|c|c|c|c|c|}
\hline \multirow{2}{*}{$\begin{array}{l}\text { Kelompok } \\
\text { Perlakuan }\end{array}$} & \multicolumn{2}{|c|}{ Kadar Glukosa Darah (mg/dL) } & \multirow{2}{*}{$\begin{array}{c}\text { Selisih } \\
\text { Rerata } \\
(\mathrm{mg} / \mathrm{dL})\end{array}$} & \multirow[b]{2}{*}{ Sig. } \\
\hline & $\begin{array}{c}\text { H6 } \\
\text { Mean } \pm \text { SD }\end{array}$ & $\begin{array}{c}\mathbf{H 2 0} \\
\text { Mean } \pm \text { SD }\end{array}$ & & \\
\hline 1 & $206,60 \pm 17,27$ & $104,80 \pm 16,71$ & 101,20 & $0.000^{*}$ \\
\hline 2 & $263,40 \pm 151.59$ & $116,40 \pm 15,95$ & 147,00 & $0.043 * *$ \\
\hline 3 & $199,80 \pm 12,24$ & $115,40 \pm 13,83$ & 84,40 & $0.043 * *$ \\
\hline 4 & $200,20 \pm 21.05$ & $115,00 \pm 20,26$ & 85,20 & $0.003 *$ \\
\hline 5 & $228,00 \pm 42,46$ & $91,40 \pm 20,23$ & 136,60 & $0.004 *$ \\
\hline
\end{tabular}

*Uji T berpasangan, **Uji Wilcoxon Sumber: Data Primer 2020

Pada tabel 6 di atas, dapat dilihat bahwa pada kelompok 3-kelompok 5 memiliki nilai $\mathrm{p}<0.05$ yang berarti terdapat perubahan kadar glukosa darah antara sebelum dan sesudah pemberian ekstrak daun salam pada kelompok tersebut, kecuali pada kelompok 1 dan kelompok 2 tidak diberi ekstrak daun salam namun juga terdapat perubahan yang bermakna. Perubahan yang paling besar terjadi pada kelompok 5 ( $\mathrm{p}=0.004)$ dengan selisih rerata 136,60 mg/dL.

Setelah dilakukan uji One Way Anova dan Kruskal-Wallis, maka dilanjutkan menggunakan uji Post Hoc LSD dan Mann-Whitney untuk melihat ada atau tidaknya perbedaan antar kelompok dengan cara membandingkan tiap kelompok perlakuan. Jika nilai $\mathrm{p}<0.05$ berarti terdapat perbedaan yang bermakna. Hasil dapat dilihat pada tabel berikut.

Tabel 7. Hasil uji Post Hoc LSD dan Mann-Whitney

\begin{tabular}{|c|c|c|c|c|c|c|c|c|c|}
\hline \multirow{3}{*}{\multicolumn{2}{|c|}{$\begin{array}{l}\text { Kelompok } \\
\text { Perlakuan }\end{array}$}} & \multicolumn{8}{|c|}{ Waktu } \\
\hline & & \multicolumn{2}{|c|}{ H1 } & \multicolumn{2}{|c|}{ H6 } & \multicolumn{2}{|c|}{ H13 } & \multicolumn{2}{|c|}{ H20 } \\
\hline & & $\begin{array}{c}\text { Mean } \\
\text { Difference }\end{array}$ & Sig. & $\begin{array}{c}\text { Mean } \\
\text { Difference }\end{array}$ & Sig. & $\begin{array}{c}\text { Mean } \\
\text { Difference }\end{array}$ & Sig. & $\begin{array}{c}\text { Mean } \\
\text { Difference }\end{array}$ & Sig. \\
\hline \multirow{4}{*}{1} & 2 & -13.80 & $0.225^{*}$ & -56.80 & $0.753 * *$ & 12.80 & $0.417 *$ & -11.60 & $0.309 *$ \\
\hline & 3 & -43.40 & $0.001 *$ & 6.80 & $0.396 * *$ & 25.00 & $0.121^{*}$ & -10.60 & $0.352 *$ \\
\hline & 4 & -24.20 & $0.040 *$ & 6.40 & $0.599 * *$ & -13.20 & $0.403 *$ & -10.20 & $0.370 *$ \\
\hline & 5 & -39.20 & $0.002 *$ & -21.40 & $0.597 * *$ & 17.00 & $0.284 *$ & 13.40 & $0.242 *$ \\
\hline \multirow{3}{*}{2} & 3 & -29.60 & $0.014 *$ & 63.60 & $0.832 * *$ & 12.20 & $0.439 *$ & 1.00 & $0.929 *$ \\
\hline & 4 & -10.40 & $0.357 *$ & 63.20 & $0.602 * *$ & -26.00 & $0.108^{*}$ & 1.40 & $0.901 *$ \\
\hline & 5 & -25.40 & $0.032 *$ & 35.40 & $0.597 * *$ & 4.20 & $0.788^{*}$ & 25.00 & $0.036^{*}$ \\
\hline \multirow{2}{*}{3} & 4 & 19.20 & $0.097 *$ & -0.40 & $1.000 * *$ & -38.20 & $0.022 *$ & 0.40 & $0.972 *$ \\
\hline & 5 & 4.20 & $0.707 *$ & -28.20 & $0.236 * *$ & -8.00 & $0.610^{*}$ & 24.00 & $0.043 *$ \\
\hline 4 & 5 & -15.00 & $0.189 *$ & -27.80 & $0.346^{* *}$ & 30.20 & $0.065^{*}$ & 23.60 & $0.046^{*}$ \\
\hline
\end{tabular}

*Uji LSD, **Uji Mann-Whitney

Sumber: Data Primer 2020

Pada tabel 7 di atas, dapat dilihat bahwa pada $\mathrm{H} 1$ terdapat perbedaan kadar glukosa darah yang bermakna antara kelompok 1 vs kelompok 3, kelompok 1 vs kelompok 4, kelompok 1 vs kelompok 5, kelompok 2 vs kelompok 3, dan kelompok 2 vs kelompok 5. Ditemukan perbedaan yang bermakna dengan nilai p > 0,05. Pada H6 didapatkan bahwa tidak terdapat perbedaan kadar glukosa darah yang bermakna pada seluruh kelompok (nilai $p>0,05$ ). Namun, pada H13 didapatkan adanya perbedaan kadar glukosa darah yang bermakna antara kelompok 3 vs kelompok 4 (nilai p < 0,05), sedangkan pada H20 didapatkan adanya perbedaan kadar glukosa darah yang bermakna antara kelompok 
2 vs kelompok 5, kelompok 3 vs kelompok 5, serta kelompok 4 vs kelompok 5. Ditemukan perbedaan yang bermakna dengan nilai $\mathrm{p}<0,05$.

\section{PEMBAHASAN}

Penelitian ini dilakukan untuk mengetahui pengaruh ekstrak daun salam (Eugenia polyantha) terhadap kadar glukosa darah pada mencit (Mus musculus). Penelitian ini menggunakan mencit jenis jantan berumur 2-3 bulan dengan berat badan 20-30 gram. Mencit jantan dipilih karena mempunyai kecepatan metabolisme obat yang lebih cepat dengan kondisi biologis yang lebih stabil dibandingkan dengan mencit betina. Mencit jantan pada usia 2-3 bulan adalah mencit dewasa muda yang mempunyai keadaan fisiologik yang optimum . Mencit sebanyak 25 ekor dibagi ke dalam 5 kelompok dengan masing-masing kelompok berjumlah 5 ekor mencit. Mencit diadaptasikan selama 7 hari agar dapat menyesuaikan diri dengan lingkungannya. ${ }^{7,8}$

Setelah diadaptasikan, pada penelitian Kusmawati et al. (2016) mencit dipuasakan selama 16 jam dan diukur kadar glukosa darah awal (H1). Hasil pengukuran menunjukkan bahwa kadar glukosa darah dengan nilai rerata $119,00 \mathrm{mg} / \mathrm{dL} \pm 12,23-158,20 \mathrm{mg} / \mathrm{dL} \pm 12,26$ berarti seluruh hewan coba memiliki kadar glukosa darah yang normal, yaitu $62,8-176 \mathrm{mg} / \mathrm{dL} .{ }^{8,9}$

Mencit diinduksi aloksan monohidrat dengan dosis $70 \mathrm{mg} / \mathrm{kgBB}$ secara intraperitoneal. Aloksan merupakan salah satu senyawa kimia diabetogenik yang sering digunakan pada hewan coba. Senyawa ini dipilih sebagai agen penginduksi diabetes karena memiliki kemampuan untuk membuat hewan coba mengalami kondisi sama seperti pasien diabetes mellitus. Aloksan bersifat toksik selektif terhadap sel $\beta$ pankreas yang memproduksi insulin karena terakumulasinya aloksan melalui transporter glukosa (GLUT 2) yang bereaksi dengan merusak substansi esensial di dalam sel $\beta$ pankreas, sehingga berkurangnya granula-granula pembawa insulin di dalam sel $\beta$ pankreas. Fase ini terjadi selama 24-48 jam hingga mengalami hiperglikemia permanen. ${ }^{6,8,10}$ Pada penelitian ini peningkatan cukup bervariasi disebabkan karena respon tubuh tiap mencit terhadap aloksan berbeda sehingga mengalami peningkatan kadar glukosa darah yang berbeda. Peningkatan kadar glukosa darah oleh aloksan disebabkan karena terjadi kerusakan pada sel $\beta$ pankreas. $^{8}$

Pada tabel 7, dimana pada uji Post Hoc LSD dan Mann-Whitney menunjukkan bahwa terdapat perbedaan antara tiap kelompok perlakuan dimana terjadi penurunan kadar glukosa darah yang bermakna pada H13 dan H20. Hal ini ditunjukkan pada H13 antara kelompok 3 (ekstrak $250 \mathrm{mg} / \mathrm{kgBB}$ ) vs kelompok 4 (ekstrak $500 \mathrm{mg} / \mathrm{kgBB}$ ) serta pada H20 antara kelompok 2 (kontrol positif) vs kelompok 5 (ekstrak 1000 mg/kgBB), kelompok 3 (ekstrak $250 \mathrm{mg} / \mathrm{kgBB}$ ) vs kelompok 5 (ekstrak $1000 \mathrm{mg} / \mathrm{kgBB}$ ), dan kelompok 4 (ekstrak $500 \mathrm{mg} / \mathrm{kgBB}$ ) vs kelompok 5 (ekstrak $1000 \mathrm{mg} / \mathrm{kgBB}$ ), sehingga dapat disimpulkan bahwa perbedaan ini bermakna pada kelompok tersebut.

Pada penelitian ini ekstrak daun salam dapat menurunkan kadar glukosa darah pada mencit yang diinduksi aloksan. Efektivitas ekstrak daun salam lebih baik pada dosis $1000 \mathrm{mg} / \mathrm{kgBB}$ yang diberikan pada kelompok 5 dalam penelitian ini. Penelitian ini sejalan dengan penelitian sebelumnya yang dilakukan oleh Studiawan dan Santosa et al. (2005) menyatakan bahwa ekstrak daun Eugenia polyantha dengan dosis 2,62 mg/20 grBB dan 5,24 mg/20 grBB dapat menurunkan secara bermakna kadar glukosa darah pada mencit jantan yang diinduksi aloksan. Dalam 
penelitian tersebut dikatakan bahwa diduga senyawa glikosida flavonoid yang terkandung dalam daun salam bertindak sebagai penangkap radikal bebas (hidroksil) yang dapat merusak sel $\beta$ pankreas sehingga dapat mencegah aksi diabetogenik dari aloksan. ${ }^{4,8}$

Penelitian ini juga sejalan dengan penelitian yang dilakukan oleh Ita Lutfiana Dewi et al. (2013) menyatakan bahwa ekstrak etanol daun salam dengan dosis 312,5 mg/kgBB, dosis $625 \mathrm{mg} / \mathrm{kgBB}$, dan dosis $1250 \mathrm{mg} / \mathrm{kgBB}$ mampu menurunkan kadar glukosa darah pada tikus yang diinduksi aloksan dengan dosis $150 \mathrm{mg} / \mathrm{kgBB}$ hingga 77 $\mathrm{mg} / \mathrm{dL}, 64,4 \mathrm{mg} / \mathrm{dL}$, dan $71,2 \mathrm{mg} / \mathrm{dL}^{6}$

Demikian pula dengan penelitian yang dilakukan oleh Nur Hikmah et al. (2016) menemukan hasil bahwa pemberian ekstrak daun salam berpengaruh secara signifikan dalam menurunkan kadar glukosa darah pada mencit yang diinduksi aloksan. Dalam penelitian ini juga dilakukan uji fitokimia untuk mengetahui adanya senyawasenyawa yang terkandung dalam daun salam, salah satunya yaitu flavonoid dan hasilnya menunjukkan bahwa daun salam positif mengandung senyawa flavonoid. Senyawa inilah yang dapat berperan sebagai antidiabetes. Dalam penelitian tersebut, dikatakan bahwa flavonoid diketahui mampu menangkap radikal bebas ROS (Reactive Oxygen Species) atau RNS (Reactive Nitrogen Species) melalui transfer elektron serta menghambat reaksi peroksidasi. Flavonoid dapat bekerja secara langsung terhadap sel $\beta$ pankreas dengan memicu pengaktifan kaskade sinyal cAMP (cyclic Adenosine Monophosphate) dalam memperkuat sekresi insulin yang disensitisasi oleh glukosa (Brahmachari, 2011) ${ }^{8,10}$

\section{KESIMPULAN}

Berdasarkan hasil penelitian yang telah dilakukan, maka dapat disimpulkan bahwa terdapat adanya perubahan bermakna kadar glukosa darah sebelum dan sesudah pemberian diet standar pada mencit, terdapat adanya perubahan bermakna kadar glukosa darah sebelum dan sesudah pemberian aloksan monohidrat dengan dosis $70 \mathrm{mg} / \mathrm{kgBB}$ pada mencit, terdapat adanya perubahan bermakna kadar glukosa darah sebelum dan sesudah pemberian ekstrak daun salam dengan dosis $250 \mathrm{mg} / \mathrm{kgBB}$ pada mencit, terdapat adanya perubahan bermakna kadar glukosa darah sebelum dan sesudah pemberian ekstrak daun salam dengan dosis $500 \mathrm{mg} / \mathrm{kgBB}$ pada mencit, terdapat adanya perubahan bermakna kadar glukosa darah sebelum dan sesudah pemberian ekstrak daun salam dengan dosis $1000 \mathrm{mg} / \mathrm{kgBB}$ pada mencit, serta terdapat adanya pengaruh ekstrak daun salam dalam menurunkan kadar glukosa darah pada mencit, akan tetapi lebih efektif dengan dosis $1000 \mathrm{mg} / \mathrm{kgBB}$ dibandingkan dengan dosis $250 \mathrm{mg} / \mathrm{kgBB}$ dan dosis 500 $\mathrm{mg} / \mathrm{kgBB}$. 


\section{DAFTAR PUSTAKA}

1. Anonim. 2014. Diabetes Mellitus. Universitas Lampung Sumatera. Diakses pada 24 Maret 2018: http://www.digilib.unila.ac.id.

2. Soelistijo, SA. dkk. 2015. Konsensus PERKENI: Pengelolaan dan Pencegahan Diabetes Mellitus Tipe 2 di Indonesia. Jakata: PB. PERKENI. Hal. 6-10.

3. Studiawan, H. Santoso, M.H. 2005. Uji Aktivitas Penurunan Kadar Glukosa Darah Ektrak Daun Eugenia Polyantha pada Mencit yang Diinduksi Aloksan Vol. 21 No. 2. Universitas Airlangga Surabaya. Hal. 62.

4. Parisa, N. 2016. Efek Ekstrak Daun Salam pada Kadar Glukosa Darah Vol. 1 No. 2. Bagian Farmakologi Fakultas Kedokteran Universitas Sriwijaya Sumatera. Hal. 404-405.

5. Arda, D. 2016. Pengetahuan Perawat tentang Penggunaan Insulin pada Pasien Diabetes Mellitus di RS Islam Faisal Makassar Vol. 1 No. 1. Makassar. Hal. 923.

6. Dewi, IL. 2013. Uji aktivitas Antidiabetes Ekstrak Etanol Daun Salam (Eugenia polyantha) terhadap Tikus Galur Wistar yang Diinduksi Aloksan. Fakultas Farmasi Universitas Muhammadiyah Surakarta. Hal. 3.

7. Anonim. 2012. Klasifikasi Mencit (Mus musculus). Jurusan Agrikultur Institut Pertanian Bogor. Diakses pada 12 April 2018: http://repository.ipb.ac.id.

8. Hikmah, Nur. dkk. 2016. Pengaruh Pemberian Ekstrak Daun Salam (Syzygium polyanthum Wight.) terhadap Glibenklamid dalam Menurunkan Kadar Glukosa Darah Mencit (Mus musculus) yang Diinduksi Aloksan. Jurusan Farmasi Fakultas FMIPA Universitas Tadulako, Palu, Indonesia. Hal. 25-29.

9. Kusumawati, D. 2016. Bersahabat dengan Hewan Coba. Yogyakarta: Gadjah Mada University Press. Hal. 7, 8, dan 88 .

10. Rohilla, A. Ali, S. 2012. Alloxan Induced Diabetes: Mechanism and Effects Vol.3 (2). Department of Pharmaceutical Sciences, Shri Gopi Chand Group of Institutions, Baghpat, Uttar Pradesh, India. Page 819821.

11. Rizki, MI. 2015. Aktivitas Farmakologis, Senyawa Aktif, dan Mekanisme Kerja Daun Salam (Syzygium polyanthum Wight). Fakultas Farmasi FMIPA Universitas Lambung Mangkurat Banjarbaru. Hal. 241. 